\title{
SoĞUK SAVAŞ SONRASI DönEM KARADENIZ'DE GÜÇ MÜCADELESİ
}

Ísmail KÖSE $E^{* *}$

\begin{abstract}
ÖZ
Soğuk Savaş bittikten hemen sonra Karadeniz Havzası'nda son yüzyılda oluşan güç dengesi bozuldu. Böylece bölge geniş anlamda alışldık üstünlük mücadelesinin ötesinde küresel çıkar çatışmalarına sahne olmaya başlamıştır. Karadeniz ve çevre çapındaki hinterlant topraklarda biçimlenen yeni güç mücadelesi asimetrik olduğu kadar tarihte ilk defa hibrit özelliklere de sahiptir. Yeni güç mücadelesinde yakın aktörlerle birlikte yeni düzenin uzak aktörleri de yer almıştır. Çarlık Rusyası, büyük güç statüsüne yükselebilmesinin Karadeniz ve Doğu Akdeniz hâkimiyeti sayesinde gerçekleşebileceğini biliyordu. Benzer şekilde Soğuk Savaş sonrasının ilk döneminde rakipsiz kalan hegemon güç $\mathrm{ABD}$; Balkanları rehabilite edip sınırlarını Karadeniz'e kadar uzatmak isteyen AB; Karadeniz ve yakın çevresini yaşam sahası olarak görüp, bu bölgede sahildar olmayan güce tahammül etmek istemeyen Rusya Federasyonu ve mevcut statükoyu, dengelenmiş kuvvet dengesi içinde muhafaza etmeyi arzulayan Türkiye yeni güç mücadelesinin taraflarını oluşturmuşlardır. Tarafların çıkarları kontjonktürel olarak uzlaşıp zaman zaman çatıştı̆ıından, Asya ile Avrupa arasındaki alternatif enerji kaynaklarının, kadim ticaret yollarının ve bölge deniz hâkimiyet merkezinin kavşağında yer alan Karadeniz Havzası, umulmadık ittifak ve rekabet gruplaşmalarına sahne olmaktadır. $\mathrm{Bu}$ çalışmada son 30 yılda Karadeniz Havzası'nda gerçekleşen güç mücadelesi analiz edilmeye çalışlacak, Havza'da faaliyet halinde olan başat aktörlerin dış politika öncelikleri değerlendirilecektir.
\end{abstract}

Anahtar Sözcükler: Rusya, Karadeniz, Boğazlar, Hegemonya, Montrö, Güç Dengesi

\section{POWER STRUGGLE IN THE BLACK SEA IN POST-COLD WAR PERIOD}

\begin{abstract}
After the end of the Cold War, the balance of power in the Black Sea Basin in the last century was disrupted. The region has attracted global interest and triggered conflicts of interest in addition to the existing tension since then. Not only asymmetrical but also hybrid characteristics unprecedented in history appeared due
\end{abstract}

* Gönderim Tarihi: 06.02.2020 Kabul Tarihi:15.07.2020.

** Doç. Dr., KTÜ İiBF Uluslararası İlişkiler Bölümü TRABZON. ismailkosetr@ktu.edu.tr ORCID: 0000-0002-8489-5088. 
to the new power struggle in the regional hinterland across the Black Sea region and the periphery. The new power struggle concerns the distant actors of the new order as well as the regional actors. The parties of the new power struggle are as follows: the US, which aims to remain the hegemonic power unrivalled in the first period after the Cold War; EU, which desires to rehabilitate the Balkans and extend their borders to the Black Sea; Russian Federation, which claims the Black Sea and near Basin as its zone of dominance, being reluctant to see any foreign power in this area; and, Turkey, which hopes to keep the status quo in the region to continue the existing balance. Tsarist Russia knew that it could achieve its rise to the status of great power thanks to the domination of the Black Sea and the Eastern Mediterranean. The interests of these countries occasionally face serious conflicts, whereas they sometimes compromise with each other. That is why the Black Sea at the crossroads of alternative energy lines and ancient trade routes connecting Asia and Europe has initiated unpredictable alliances and rivalries. This paper deals with the power struggle during the last 30 years in the Black Sea Basin and analyses the parameters of foreign policy priorities of certain outstanding actors in the region.

Keywords: Russia, Black Sea, Turkish Straits, Hegemony, Montreux, Balance of Power

\section{Giriş}

Rusların 9. yüzyılda Novgrod'da başlayıp, aynı yüzyılda Rurik tarafından açık denize ulaşım sağlayan Dinyeper (Turla) nehri kıyısındaki Kiev'e taşınan Knezliği'nden Çarlığa giden süreçte Karadeniz'in oynadığı yaşamsal rol I. Petro başta gelmek üzere Çarlar tarafindan hep hatırda tutulmuştur. Nitekim Ruslar'ın tarih boyunca Karadeniz'i "Vaat Edilmiş Havza", "Kutsal Kâse" şeklinde telakki ettikleri, hegemon güç olunabilmesi için Karadeniz' in kontrol edilmesi gerektiğine inanıldığı bilinmektedir. ${ }^{1}$ Çarlığın I. Petro sonrasında Türk Boğazları'nda söz hakkına sahip olabilmek için bir düzine kanlı savaşı göze alması, ilkokul kitaplarında bile 1791 yılı Temmuz ayında Çiligra (Kaliakra) Burnu Savaşı'nda Osmanlı Donanmasını yenmeyi başaran Amiral Uşakov'un ulusal kahraman olmanın yanında "Kutsal Bir Aziz" olduğunun da öğretilmesi söz konusu savı güçlü şekilde desteklemektedir. ${ }^{2}$

Karadeniz; coğrafi olarak Asya ile Avrupa kıtalarını buluşturan, iç çap halka havzada Balkanlar, Rusya, Kafkaslar ve Anadolu; daha geniş bir perspektifle dış çap halka havzada Rus stepleri, Hazar Denizi, Türkistan, Doğu Akdeniz, Ortadoğu ve Orta Avrupa'nın kesiştiği bir noktada yer alır. Boğazların yegâne çıkış sağladığı bu kritik bölge yakın ve uzak çevresine sağladığı erişim

1 New Strategy Center Policy Paper-2019, "Militarization in the Black Sea and Eastern Mediterranean Theatres, A new Challenge to NATO", https://newstrategycenter.ro/wpcontent/uploads/2019/02/Policy-Paper-New-Strategy-Center-Centro-Studi-Internazionali 2019.pdf (01 Haziran 2020 tarihinde erişildi). s. 5.

2 New Strategy Center Policy Paper-2019...., s. 5. 
olanaklarıyla dünya denizlerinin en stratejik yerlerinden birisidir. Nitekim Karadeniz Havzası tarih boyunca gerek Avrupa, Asya gerekse Anadolu'nun güvenliği için vazgeçilmez önemde olmuştur. Avrupa, Asya ve Ortadoğu'nun kavşak noktasında, enerji kaynaklarının geçiş koridorunda yer alan bu stratejik Havza kadim ticaret yollarının da ana akslarından birisidir. ${ }^{3}$ Bunlara ek olarak, iç ve dış havzasıyla bir bütün olarak değerlendirildiğine Karadeniz'in küresel ehemmiyeti boyutunun çok ötesinde olduğu açıktır. $\mathrm{Bu}$ nedenle Karadeniz Havzası, uluslararası aktörlerin siyasi ve ekonomik güvenliklerini doğrudan etkileyebilme potansiyeline sahiptir. ${ }^{4}$

Tarih boyunca, Avrupa, Asya ve Afrika'ya giden yolların kesişme noktasında bulunan Karadeniz Havzası'nı kontrol edebilen güç ya da güçler aynı zamanda Balkanlar, Avrupa, Doğu Akdeniz ve Güney Kafkasya ile Ortadoğu'nun kuzey kısımlarını da kontrol edebilmişlerdir. Bu çok bileşenli hibrit Havzanın kilidi Türk Boğazları, son yüzyılda anahtarıysa 84 yıldır yürürlükte olan Montrö Boğazlar Sözleşmesi'dir. Boğazlardan; süre, tonilato, sınıf ve kullanım amacı sınırlamalarına tabi olmadan savaş gemisi, uçak gemisi ve denizaltı geçirebilen tek ülke Türkiye Cumhuriyeti'dir. Sanayi Devrimi sonrasında gerek askeri teçhizat gerekse denizcilik ve ulaşım alanlarında yaşanan hızlı gelişmeye rağmen Karadeniz ve dolayısıyla Türk Boğazları önemlerini kaybetmek bir yana gün geçtikçe daha fazla önem kazanmaktadırlar. Boğazların kazandığı ehemmiyet konjonktürel olarak bazen askeri bazen da ticari olabilmektedir.

Osmanlı Devleti Karadeniz'in kuzeyini ve Kafkasların bulunduğu doğu kısmını son 19. yüzyılın sonundaki savaşlarla kaybetmiş, Anadolu gerek Karadeniz üzerinden gerekse doğudan Rus tehdidi altına girmiştir. I. Dünya Savaşı esnasında Rus orduları gerek Karadeniz’i kullanarak gerekse doğudan Trabzon Limanı dahil Anadolu’nun önemli kısmını işgal edebilmişlerdir. Her ne kadar 1918 yılı Mart ayında imzalanan Brest Litovsk Antlaşması ile Karadeniz kıyısında Rusya'ya kaybedilen toprakların bir bölümü geri alınıp, Karadeniz'in yakın ve uzak kıyısındaki devletlerin bağımsızlıkları tanınarak Rusya'ya karşı bir set oluşturulmaya çalışılmış olsa da, Sevr ile bu kazanımların hemen tamamı elden çıkmıştır. ${ }^{5}$ Milli Mücadele sonrasında Doğu Sınırı Karadeniz güvenliği sağlanacak şekilde oluşturulup, Sevr ile kaybedilenlerin Batum haricindeki kısmı geri alınabildi.

Cumhuriyet kurulduktan hemen sonra Karadeniz'in sağlayabileceği askeri, ticari ve stratejik önemin farkında olan Cumhurbaşkanı Mustafa Kemal [Atatürk], Karadeniz kıyısındaki limanların modern şartlara uygun olarak

3 Yevgeniya Gaber, "Security Triangle in the Black Sea Region: Turkey, Russia, United States", Panaroma of Global Security Environment 2017-2018, Ed. Robert Ondrejcsak vd., Stratpol, Bratislava, 2018. s. 198.

4 Blue Black Sea: New Dimensions of History, Security, Politics, Strategy, Energy and Economy, Ed. G. Saynur Bozkurt, Cambridge Scholars Publishing, UK, 2013. s. 3.

5 Türkiye Cumhuriyeti Cumhurbaşkanlı̆̆ Devlet Arşivleri (BOA), HR. SYS. 02295.00002.001. 17/01/1918. 
yapılandırılıp, Anadolu ile demiryolu bağlantılarının ivedilikle sağlanması talimatını vermiştir. Bu kapsamda Karadeniz'in Kafkasya sınırını kontrol edip, Anadolu'nun doğusu, Nahcivan, Azerbaycan üzerinden Atayurt Türkistan'a ve İran'a bağlantı sağlayan limanlara özel önem verilmiştir. $\mathrm{Bu}$ kapsamda Cumhuriyet kurulduktan bir yıl sonra 1924 yılı başında Trabzon ve Samsun limanlarının günün koşullarına uygun hale getirilmesi için inşa faaliyetlerinin başlatılmasına karar verilmiştir. Her iki limanın inşa imtiyazı bu dönemde Türkiye Bankası'nın elindedir. ${ }^{6}$ Aynı yılın sonunda Trabzon Limanı'nın inşasıyla Erzurum-Trabzon arasında Samsun-Sivas ve Kütahya-Tavşanlı arasında olduğu gibi demiryolu hattı yapılmasına karar verilmiştir. Bu işlem için ek bütçe tahsis edilmiştir. ${ }^{7}$ Her iki liman da modernize edilmiş fakat çeşitli olumsuzluklar ve doğa şartları sonucu Trabzon limanı ile Anadolu'nun doğusu arasında demiryolu hattı inşa edilememiştir. Bu eksiklik, günümüzde bile çok sayıda lojistik, stratejik soruna neden olmaktadır.

\section{Sovyetler'in Halef Devleti Rusya Federasyonu ve Karadeniz}

Rusya Federasyonu (RF), Sovyetler Birliği'nin dağılması ve Varşova Paktı'nın resmen sona ermesinin hemen ertesinde yaşadığı kurumsal sorunlar, Don-Volga hattından bölünme endişesi dahil yapısal iç karışıklıklar ve yenilgiyle sonuçlanan I. Çeçenistan Savaşı sonrasında küresel güç olma özelliğini kaybedip, hızla bölgesel bir aktöre dönüştü. Tekrar küresel güç statüsüne yükselip, en azından eski Sovyet coğrafyasında hegemon devlet rolünü sürdürebilmek amacıyla Birleşik Devletler'e Amerika kıtasında hegemon güç statüsü sağlayan Monroe Doktrini'nin ilanından 170 yıl sonra, 1993 yılı Şubat ayında sınırlı fakat ihlali halinde sert güç kullanım tehdidi içeren Ближний Зарубеж/Blijniy Zarubejniy (Yakın Çevre) Doktrini ile birlikte bir dizi yeni politikayı uygulamaya konuldu. ${ }^{8}$ Karadeniz, yeni doktrininin güney ayağını oluşturuyordu, Kremlin Türkiye ile benzer şekilde Karadeniz'deki statükonun bozulmasını istemiyordu.

Soğuk Savaş süresince NATO, ABD ile merkez Avrupa devletlerinin çıkarlarını koruyacak bir kuvvet planlamasıyla örgütlenmiş, olası savaş konsepti de bu politikaya göre şekillendirilmişti. Türkiye, Boğazları kontrol etmesi ve Ortadoğu'ya hâkim coğrafyası sayesinde NATO'ya alınmış, fakat olası Sovyet saldırısında korunacak değil petrol kuyularının güvenliği için kolaylıkla feda edilebilecek bir savunma konseptinin parçası yapılmıştı. ${ }^{9}$ Soğuk Savaş sonrasında NATO'nun esnek karşıllk stratejisinin değişmesine bağlı olarak yeni yaklaşımlara ihtiyaç duyuldu. RF'nin gücünü yeniden kazanmaya çalıştığı ilk 10

\footnotetext{
BCA, 030.18.01.01.012.66.9. 04/01/1924.

$B C A, 080.18 .01 .01 .012 .63 .7 .31 / 12 / 1924$.

8 Mihail Meyer, "18. Yüzylldan Günümüze Rusya ve Türkiye İlişkileri”, Dünden Bugüne Türkiye ve Rusya, Der. Gülten Kazgan ve Natalya Ulçenko, İstanbul Bilgi Üniversitesi, İstanbul 2003. s. 13.

9 Melvyn P. Leffler, "Strategy, Diplomacy, and the Cold War: The United States, Turkey, and NATO, 1945-1952", The Journal of American History, C: 71, No.4, Mart 1985. s. 814-815.
} 
yılda, Varşova Paktı'nın yokluğunda bir süre yeni görev alanı konusunda tereddüt yaşanıp, gerekliliği tartışmalı hale gelen NATO’nun varlığı için 11 Eylül saldırıları can suyu oldu.

Soğuk Savaş sonrasında Karadeniz'de, hinterlant bölgeler Balkanlar, Kafkaslar, Anadolu'nun kuzey sahilleri, Don, Dinyeper ile Tuna havzaları ve Rusya'nın güney sahilleri dahil olmak üzere Büyük Karadeniz Havzası kavramsallaştırması hakim olmaya başladı. Nitekim Türkler ile Ruslar arasındaki tarihi ilişkilerin en esaslı öznesi her daim Karadeniz ile tam çap halka hâkimiyeti ve Boğazlar olagelmişti. Montrö, bazı krizlere karşın türbülanslı bir dönemde 73 yıl gibi uzun süre Boğazlar geçiş rejimini düzenleyen 1841 tarihli Londra Boğazlar Sözleşmesi'nden sonra en uzun süre yürürlükte kalabilip, her iki devletin de aynı anda belli itirazlara rağmen (Türkiye 2. maddenin getirdiği kısıtlamalara kıyı devleti olarak itiraz etmektedir) stratejik olarak yürürlüğünü istediği yegâne Sözleşmeydi.

Rusya Federasyonu, Karadeniz'deki ekonomik ve askeri gücünü kendisinden ayrılan sahildar devletlerle paylaşmak zorunda kaldı. Bu durumun doğal sonucu olarak gerek askeri gücü gerekse Karadeniz sahilindeki kıyı şeridi kısaldı. Soğuk Savaş sonrasına hazırlıksız yakalanıp yaklaşık 10 yıl süren bir bocalama dönemi geçiren RF, 2000 y1lı başından itibaren kaybettiği güç, prestij ve dünya politikasında etkin olma konumunu tekrar geri kazanabilmek için yeni bir atılım başlattı. Bu atılımda dört temel üstesinden gelinmesi güç sorunla karşılaşıld1: (1) hantallaşmış devlet bürokrasisi ve rekabetçi olmayan sanayi (2) ekonomik zorluklar, askeri kapasite azalması, Batı karşısında güçsüzlük (3) Balkanlar'ın hızla Batı eksenli ittifaklara dahil olması, bu durumun Rusya'nın Avrupa ile kara bağlantısını zora sokması (4) Devlet işleyişine hâkim olan oligarşi ve Sovyet hâkimiyet alanında yeniden kontrol kurulması ihtiyacıydı.

Askeri kudret, sürdürülebilir gelişmişlik ve ekonomik güçle karşılıklı ilişki içinde olduğundan öncelikli olarak askeri sanayinin modernize edilip, Sovyet dönemi devlet yapısındaki aksamalar sonucu kurumsallaşan verimsizlik eşliğindeki durağanlığın aşılması gerekiyordu. Ancak, rekabetçi bir üretim ortamında gerekli dinamizm sağlanabilirdi. Hızlı ekonomik toparlanma ve kalkınmanın en kestirme yolu her yıl daha fazla artan miktarda doğalgaz ve petrol ihracatıdır. Bütün bu atılımların gerçekleştirilebilmesi için, Avrupa ile kara bağlantısı zorluğu nedeniyle, güçlü bir deniz filosuna ve kapanmayacak deniz bağlantılarına ihtiyaç duyuldu. Doğal olarak Soğuk Savaş bittiğinde Türk Boğazları RF için askeri olmanın ötesinde, eko-stratejik ticari önem kazand. Böyle bir gelişme daha önce de ifade edildiği gibi bilinen Türk-Rus ilişkileri tarihinde ilk defa yaşandı. Bu gelişme ABD'nin enerji güvenliği politikalarıyla Rus çıkarlarının yakınlaşmasını sağlarken, ABD hegemonyasını RF yakın çevresine taşıyacak olan demokrasi ve güvenlik politikaları Büyük Karadeniz Havzası'nın Kafkaslardan Balkanlara uzanan iç kuzey hilal kısmındaki bölgelerde yeni çatışma alanları ortaya çıkarttı.

Rusya Federasyonu'nun küresel ölçekte dar kapsamlı sayılabilecek stratejik yaklaşımları ve yakın çevrede hükümranlık isteyen yeni güvenlik 
doktrini; yerkürenin çatışma potansiyeli taşıyan sıcak çıkar noktalarında Moskova ile cepheleşmek istemeyen ABD tarafından sessizlikle karşılandı. Karadeniz'deki güç mücadelesi de kaçınılmaz olarak bu kapsamda şekillenmeye başladı. Sovyetler'in çöküşü sonrasında Karadeniz Havzası'nda başat güç olma yolunda ilerleyen ABD, 1997 yılında Havza'daki çıkarlarını koruyabilmek, işbirliği alanlarını ortaya çıkartıp, eski Demirperde ülkelerini RF yörüngesinden çıkartıp kendi güç alanına dahil edebilmek amacıyla Karadeniz Güvenlik Programı'nı başlattı. Washington'un Karadeniz politikası: (1) demokrasi (2) enerji (3) güvenlik üçlüsü çerçevesinde şekillenmekteydi. İki yıl sonra, 1999 senesinde ABD Kongresi İpekyolu Stratejisi Kararı'nı kabul ederek söz konusu politikaların yasal temelini oluşturdu. ${ }^{10}$

Bütün bu süreci hızlandırıp, güvenliği bir süreliğine enerji politikalarının önüne koyan gelişme 2001 y1lında ve daha sonra Irak müdahalesi ertesi 2003 yılında yaşandı. $\mathrm{Bu}$ y1llarda RF halen Sovyet dönemi süper güç statüsünden oldukça uzak, kurumsal ve askeri teknolojik sorunlarının üstesinden gelememiş bir durumdaydı. ${ }^{11}$ RF'nin yeniden süper güç olamasa bile küresel aktöre dönüşebilme çalışmaları esnasında gerçekleşen 9/11 saldırıları ABD'nin Karadeniz ve hinterlant havzada daha yoğun faaliyet göstermesine neden oldu. ${ }^{12}$

İlk başta uygulamaya konulan üç prensip arasındaki demokrasi ilkesi bir kenara bırakılarak, Karadeniz Havzası'ndaki ABD çıkarları, kısa vadeli öncelikler olan enerji ve güvenlik üzerinde odaklandı. ABD, Soğuk Savaş süresince fosil yakıt kaynaklarına erişimini garanti ettiği sürece Ortadoğu'daki otokrat diktatörlüklere ses çıkartmayıp, bu baskıcı, her türlü özgürlüğü reddeden, ulus anlayışından uzak kabile temelli devlet yapılanmalarını destekleyerek gerekli tecrübeyi kazanmışı. Tıpkıbasım politika kendi dinamikleri içinde Karadeniz Havzası'nda da uygulamaya konuldu. Demokrasi prensibinin terkedilmesinin bir nedeni de Abhazya, Ermeni işgali altındaki Dağlık Karabağ ve Güney Osetya'daki çatışmaların çözümlenememiş olması, demokrasi vurgusunun özellikle Kafkaslar ve Türkistan bölgesinde dirençle karşılaşmasıydı. Oysa, sadece demokratik gelişim dış çap halkanın dahil olduğu Büyük Karadeniz Havzası'nda istikrar, halk tabanına inebilen refah ve güvenlik sorunlarına sürdürülebilir çözümler üretip, uzun vadede Karadeniz ve hinterlandını bir barış havzası haline getirebilirdi. Washington' un 9/11 saldırıları sonrasında harekete geçen refleksleri ve öncelikli çıkarları uzun vadede sonuç verebilecek bu politikanın uygulanmasina olanak birakmadi.

Olası bir Pekin, Moskova ittifakını tetiklemekten çekinip, Rusya'nın kendi yakın çevresinde meşgul olmasından memnun olan Washington, Gürcis-

10 https://www.congress.gov/bill/106th-congress/senate-bill/579 (30 Mayls 2020 tarihinde erişildi).

11 Lincoln A. Mitchell, "More than Location: Crafting a US Policy for the Black Sea Region", Southeast European and Black Sea Studies, 8 (2), 2008. s. 131.

12 Black Sea Security Program-2013, Ed. Sergei Konoplyov-Lada Roslycky-Sergey Yeremko, Harvard Publ., USA, 2013. s. 2-3. 
tan krizi sonrasında Kırım'ın ilhakına da yeni statükoyu engelleyecek düzeyde tepki göstermedi. Buna karşın ABD, NATO Barış İçin Ortaklık (BİO) projeleri kapsamında dünyada serbestçe savaş gemisi sokamadığı tek açık deniz olan Karadeniz'deki varlığını güçlendirmeye yönelik adımlar atmayı sürdürdü.

ABD'nin Havza'daki artan faaliyetlerini dikkatle takip eden RF'nin Sovyet sonrası yeni etkinlik alanları oluşturma politikası tarihte daha önce tecrübe edildiği gibi öncelikli olarak Karadeniz'e yöneldi. Çarlık Rusyası ancak Kırım'ı işgal ettikten sonra Karadeniz'de gemi yüzdürebilme hakkı elde edebilmişti. ${ }^{13}$ Kırım'daki donanma üssünün uzun süreli kiralama yöntemiyle boşaltılmayıp, daha sonra Kırım'ın, meşruluğu tartışmalı yöntemlerle ilhak edilmesi Moskova'nın Karadeniz'deki varlığının sınırlanmasını kabul etmeyeceğini tartışmaya yer bırakmayacak şekilde ortaya koydu. Kırım'1 18 Mart 2014 tarihinde gayrimeşru yöntemlerle ilhak eden RF, Karadeniz'in kuzeyindeki deniz yetki alanlarını, karasularını ve münhasır ekonomik bölgesini batıya doğru genişletti. Böylece RF'nin deniz yetki alanları Romanya ve Bulgaristan ile hemhudut olup, Ukrayna'nın Türk Münhasır Ekonomik Bölgesi ile doğrudan bağlantısı kesildi.

Cenevre'de Birleşmiş Milletler Deniz Hukuku Sözleşmesi (BMDHS) müzakereleri yapılırken, Türkiye ile Sovyetler Birliği arasında Karadeniz kıta sahanlığı sınırlandırma görüşmeleri 14-15 Haziran 1978 tarihlerinde Moskova'da yapılmıştı. ${ }^{14}$ Aynı yıllarda Bulgaristan ile de kıta sahanlığı görüşmeleri sürdürülmekteydi. ${ }^{15}$ Sovyetler ile kıta sahanlığı belirleme çalışmaları yapılırken Karadeniz'e kıyısı olan dört ülke vardı. Bugün Karadeniz'e Ukrayna ve Gürcistan'ın eklenmesiyle altı ülkenin kıyısı vardır. Dört yıl süren görüşmeler sonrasında Türkiye ile Sovyetler Birliği arasında Karadeniz'de karasularının belirlenmesi ve deniz hududunun işaretlenmesi antlaşması 1982 y1lında onaylanıp, yürürlüğe girmişti. ${ }^{16}$ Ukrayna ve Gürcistan söz konusu görüşmeler yapılırken Sovyetler'in içinde yar aldığı için Kırım'ın ilhakı sonrası RF lehine, Ukrayna aleyhine gerçekleşen deniz yetki alanı artışı Türkiye'yi doğrudan etkilemedi.

Hegemon güç olmanın olmazsa olmaz şartı denizlerde varlık gösterebilmekle yakından ilgilidir. Hegemon güç olma arzusunu sesli olarak dile getirmeden, bütün stratejilerini bu doğrultuda kurgulayıp, Pasifik'te ABD ile cepheleşen Çin, Karadeniz dahil dünyanın diğer denizlerinde de varlık göstermeyi amaçlıyordu. Tarihte ilk defa 2017 yılı Haziran ayında üç savaş gemisinden oluşan bir Çin filosu Türk Boğazları'ndan geçerek İstanbul önüne gelmiştir. Çin'in Ortadoğu'daki çıkarları kadar, denizaşırı politikasının da erişebileceği

13 Galina Grebenshchikova, "Operations on the Danube During Russo-Turkish Wars of 17681774 and 1787-1791”, Osmanl Devleti'nde Nehirler ve Göller, C: I, Haz. Şakir BatmazÖzen Tok, Not Yayınları, Kayseri 2015. s. 64-65.

$14 \quad B C A, 301812.373 .147 .11 .13 / 06 / 1978$.

$15 \quad B C A, 301812.377 .208 .17 .15 / 02 / 1979$.

$16 \quad B C A, 301812.450 .470 .6 .03 / 05 / 1982$. 
uzak sınırları gösteren bu ziyaret öncesinde, 2001 yılında Ukrayna'ya ait Varyag adlı uçak gemisi Çin'de söküleceği bahanesiyle Boğazlardan geçirilmiş, daha sonra Çin tarafından uçak gemisine dönüştürülmüştü. Varyag'ın geçişi Montrö'nün açık ihlalidir. Buna karşın Çin Varyag'ın geçişine izin verilmesi karşılığında Türkiye'nin ihtiyaç duyduğu ve ABD'nin vermediği alçak irtifa füze sistemlerini Türkiye'ye satmayı kabul etmiştir. Bütün bu gelişmeleri yakından takip eden Washington, Pekin ile RF'yi yakınlaştırabilecek politikalardan kaçınıyordu.

Yaygın görüş doğrultusunda, Batı dünyasında İngiltere ve Kara Avrupası sonrasında ABD'nin 1945 yllından itibaren hegemon bir güce dönüştügünü söylemek olasıdır. Buna karşın ABD, 2003 yılına kadar Montrö’nün amir hükümleri nedeniyle Karadeniz'e istediği ve ihtiyaç duyduğu miktarda kuvvet sokamayan bir güç olarak kalmıştır. Washington'un gerek Soğuk Savaş süresince gerekse Soğuk Savaş sonrasında kesin hatlarla belirlenip kurumsallaşmış Ortadoğu benzeri belirgin bir Karadeniz stratejisinden bahsetmek güçtür. Söz konusu strateji 9/11 saldırıları sonrasında güvenlik eksenli olarak kurumsallaşacaktır. ${ }^{17}$ İlgili Devlet katlarında planlanıp geleceğe yönelik projeksiyonlar üreten tutarlı bir strateji eksikliğine karşın Washington'un politikaları Soğuk Savaş sonrasının ilk 10 yılında Havzadaki siyasi gelişmeleri kendi yörüngesinde tutabilmek için demokrasi; çıkarlarını maksimize edebilmek için güvenlik ve teminat altına alınmış çok alternatifli fosil yakıt kaynaklarının sürdürülebilir emniyeti için enerji güvenliği prensipleri üzerinde şekillendi. ${ }^{18} \mathrm{Bu}$ doğrultuda Balkanlar'daki eski Demirperde ülkelerini Batı idealleri kapsamında kendi ittifak çemberine almayı amaçlayan ABD, Soğuk Savaş sonrasında NATO'yu bu doğrultuda etkin olarak kullanmaya başladı.

ABD ile birlikte, Avrupa Birliği (AB) de öncelikle Karadeniz Havzası'nın batı yakasını güvenlik derinliği olarak kabul edip kendisi için yıkıcı olan iki dünya savaşının da ateşinin alevlendiği bölge Balkanları konsolide ve rehabilite ederek kontrolüne alabilmek için harekete geçti. Türkiye'yi dışarda bırakıp Balkanlar'da Türkiye'den gerek ekonomik gerekse demokratik gelenek olarak çok geride olan Balkan ülkelerini içine alan AB'nin bir sonraki adımı yaşamsal ihtiyaç duyduğu enerji kaynaklarının ve nakil hatlarının güvenliği oldu. Balkanlar'ın önce NATO daha sonra AB şemsiyesi altına alınması, Soğuk Savaş süresince Yunanistan-Avusturya-Federal Almanya hattından geçen $A B$ hududunu merkez Avrupa'dan kuş uçuşu ortalama $1.000 \mathrm{~km}$. derinlikle doğuya taşıyarak Karadeniz kıyısına ulaştırdı. Böylece dünyadaki tek federal özellikli ulus üstü çoklu siyasi, hukuki ve ekonomik birliktelik olan $\mathrm{AB}$ kuzeyde Baltık ve Norveç Denizleri, güneyde Akdeniz, batıda Atlas Okyanusu ile sınırken tarihinde ilk defa doğuda Karadeniz ile de sınır oldu.

Gaber, a.g.m., s. 205.

18 Sergei Konoplyov ve Igor Delanoe, "Continuities and Ruptures: Tracking the US Interests in the Black Sea Area in the Context of the 'Pivot Asi”, Black Sea Security Program-2013, Ed. Sergei Konoplyov-Lada Roslycky-Sergey Yeremko, Harvard Publ., USA 2013, s. 4-5. 
ABD; Romanya ve Bulgaristan’ın 2004 yılında NATO’ya üye olmasıyla Karadeniz kıyısında üsler elde edip, bu denize de dolaylı olarak belli sınırlar içinde erişebildi. İkinci adım Romanya'nın Karadeniz kıyısında bir üs kurulması girişimi odu. Romanya, gerek Ploieşti merkezli petrol kaynakları gerekse Ukrayna’ya yakınlığıyla stratejik önemdedir. Buna karşın Romanya'nın birkaç demode firkateyn ve altı korvetten oluşan deniz gücü herhangi bir askeri etkiden uzaktı. ${ }^{19}$ Romanya topraklarında, Tuna Nehri ortalarında bir üs kurulması teşebbüsü II. Dünya Savaşı sonrasında da gündeme gelmiş, bu girişimden sonuç alınamamıştı. Washington, burada kuracağı üs ile Romanya'nın deniz gücünü artırarak, AB'nin doğu sınırı Karadeniz'in güvenliğini sağlayıp, Rus irredentizmini engellemeyi amaçliyordu.

Eski Demirperde ülkeleri de halen Rusya'dan etkili tehdit algıliyorlardi. $\mathrm{Bu}$ nedenle bir an önce NATO ve AB güvenlik şemsiyesi altına girmek arzusundaydilar. Nitekim Romanya ve Bulgaristan üye olduktan hemen sonra kaçakçılığın önlenebilmesi adı altında Karadeniz'e NATO gücü yerleştirilmesini istediler. Bu talep Montrö koşulları ileri sürülerek Rusya tarafından şiddetli itiraz gördü. Karadeniz'de faaliyet göstermek için sahildar devletler tarafindan kurulan BLACKSEAFOR girişimine NATO'nun aktif destek vermesi de Kremlin'in itirazıyla karşılaştı. ${ }^{20}$ Rusya, SSCB donanmasını Ukrayna ile paylaştığından bu yıllarda Karadeniz'deki en büyük deniz gücü Türkiye'ye aitti. Soğuk Savaş sonrasında yaklaşık 20 yıl sürüp, Moskova'yı rahatsız eden bu üstünlük, 2008 yılı sonrasında Rusya lehine değişti. Gürcistan Krizi de tam bu dönemde patlak verdi.

Karadeniz'de askeri anlamda Washington, Moskova ilişkilerinde ilk krize varacak gelişme yıllardır süren Gürcistan iç savaşı esnasında 2008 yılı Ağustos ayında yaşandı. Gürcü kuvvetlerinin ayrılıkçı özerk bölge Güney Osetya’yı sivil ya da askeri hedef gözetmeksizin topa tutması üzerine, RF, ABD tarafindan desteklenen Gürcistan'a karşı ABD’yi hiçe sayacak derecede orantısız sayılabilecek büyüklükte askeri güçle müdahalede bulundu. Rusya'nın müdahalesine karşı varlık göstermek zorunda kalan ABD, insani yardım adı altında savaş gemilerini Karadeniz'e göndermek istedi. Montrö Sözleşmesi'ne göre sahildar olmayan devletler, 45.000 üst limite ek olarak 8.000 tonilatoya kadar insani yardım gemilerini Boğazlardan Karadeniz’e gönderme hakkına sahiptirler (madde 18/d). Kafkasların anahtarı olan Gürcistan, ABD destek ve teşvikiyle Rusya karşıtı politikalar geliştirdiğinden, bu devletin orantısız Rus gücü ve saldırganlığı karşısında yalnız bırakılmaması gerekiyordu. Washington ise beklentilerin aksine Kremlin'le askeri cepheleşmeye niyetli değildi. Gürcistan Krizi sonucu Karadeniz'deki güç mücadelesinin ilk raundunu Moskova kazandi. Müdahale Rus varlığını ve sert güç diplomasisini güçlendirirken ABD’nin prestij kaybetmesine neden oldu.

19 George Friedman, "Ukraine, Iraq and a Black Sea Strategy", https://worldview. stratfor.com/article/ukraine-iraq-and-black-sea-strategy (30 Mayıs 2020 tarihinde erişildi).

$20 \mathrm{https}: / /$ www.dzkk.tsk.tr/icerik.php?icerik_id=242\&dil=1\&blackseafor=1 (30 Mayls 2020 tarihinde erişildi). 


\section{Karadeniz'de Krizler: Örtülü Amerikan-Rus Cepheleşmesi}

Karadeniz'de offensive realist politikaların uygulamaya konulmasını engelleyebilecek liberal, ulus üstü düzeyde ortak kurumsallaşma henüz gerçekleşmemiştir. Türkiye'nin öncülük ettiği Karadeniz Ekonomik İşbirliği Örgütü (KEI) çok fazla etkin olmasa da RF'nin üye olduğu tek batı menşeli kuruluştur. KEİ, NATO Barış İçin Ortaklık projesi dahil dar kapsamlı girişimler haricinde Karadeniz'de RF'nin ortak olduğu herhangi bir ulus üstü barış amaçlı birliktelik mevcut değildir. $\mathrm{Bu}$ nedenle Karadeniz'deki güç mücadelesinin seyrinin offensive realist perspektifte nereye kadar tırmanacağında Rus kudretini karşılayabilecek halen tek yegâne güç ABD'nin politikaları belirleyici olmaktadır.

$\mathrm{RF}$ ile güç mücadelesinin uzak aktörü $\mathrm{ABD}$, yakın aktörü ise NATO üyesi Türkiye'dir. Buna karşın Türkiye ile NATO ve ABD'nin çıkarları konjonktürel olarak hem Karadeniz'de hem de Balkanlar ve Kafkaslar'da çatışabilmektedir. Bu nedenle Soğuk Savaş sonrası dönemde Soğuk Savaş'tan farklı olarak müttefikler arasında bile bazen işbirliği bazen de cepheleşmeler yaşanabilmektedir. Bu durum Karadeniz'de çok aktörlü bir güç mücadelesine neden olmaktadır. Karadeniz'in kilidi Türk Boğazları olduğundan her ne kadar güç mücadelesinde hegemon kudrette bir aktör olamasa da Türkiye, Boğazları kontrol ettiğinden önemli bir avantaja sahiptir. Boğazlarda Montrö'nün uygulanması esnasında RF ve Karadeniz'de varlık göstermek isteyen ABD ile sorunlarla karşılaşı1maktadır. Gürcistan Krizi söz konusu problemlerin gün yüzüne çıkmasına neden oldu.

ABD, 1999 yılında Çekya, Macaristan, Polonya; 2004 yılında Litvanya, Letonya, Estonya, Bulgaristan, Romanya gibi Balkan ülkelerinin NATO üyeliğine geçmesiyle son 10 yılda Karadeniz'deki varlığını artırmıştı. ${ }^{21}$ Karadeniz Havzası'nda, Rus saldırganlığına vereceği karşılık bölge ülkeleri için güvenilirlik testine dönüssen $\mathrm{ABD}$, Rusya ile çatışmaya varabilecek müdahaleye niyetli olmadığından Boğazları Montrö'yü hiçe sayarak kullanmaya karar verdi. Türkiye, Gürcistan'ın toprak bütünlügünü savunuyor, Rusya'nın Kafkaslar'da tekrar güç kazanmasını istemiyordu. Montrö'nün tartı̧̧maya açılması da, istenilen bir durum değildi. Gürcistan'a yegâne ulaşım ya Türkiye üzerinden ya da Boğazlardan geçilerek Karadeniz üzerinden mümkündü. Askeri destek girişimini barışçıl amaç altına gizlemeyi arzulayan $\mathrm{ABD}$, iki hastane gemisi USNS Mercy ve USNS Comfort'u Karadeniz'e göndermek istedi. İki geminin toplam ağırlığı 69.000 tondu. Bu ağırlık azami 45.000 ton olabilecek Montrö'nün 18. maddesiyle izin verilen limitlerin çok üzerindedir. Karadeniz'deki Amerikan varlığının artmasından uzun süredir rahatsız olan Kremlin, ABD hastane gemilerinin geçişinin Montrö'ye aykırı olduğunu ilan etti. Montrö’yü tartı̧̧maya açmak istemeyen Türkiye, NATO müttefiki Amerikan gemilerine geçiş izni vermedi. Aslında istenilen yardım havayoluyla daha hızlı ve kolay ulaştırılabilirdi. Rusya ile doğrudan cepheleşmeden kaçınan Washington'un

21 Radu Dudau, “The Black Sea: Romania's Energy Gateway”, Black Sea Security Program2013, Ed. Sergei Konoplyov-Lada Roslycky-Sergey Yeremko, Harvard Publ., USA 2013. s. 78. 
öncelikli amacı sert güç kullanılmamasına bahane bulup, daha önceki yıllarda da yapıldığı gibi bu bahaneyle Montrö'yü delmekti. ${ }^{22}$ Ankara ise Montrö’yü ve statükoyu korumaya kararliydı.

Geçiş izni verilmemesi ABD’de Türkiye karşıtı eleştirilere sebebiyet verdiyse de karar değişmedi. ABD, Ukrayna ve Gürcistan üzerinden Karadeniz'deki varlığını güçlendirmek isterken, Rusya ABD’nin NATO vasıtasıyla ya da yalnız başına kendisi tarafından arka bahçe olarak telakki edilen bir bölgeye ulaşmasına karşı çıkıyordu. Bu politika halen değişmemiştir. Rusya'nın, ABD’yi Karadeniz'den uzak tutmasının yegâne yolu Montrö Boğazlar Sözleşmesi'dir. Bu yüzden Moskova, Montrö'nün hiçbir şekilde tartışmaya açılmasına taraf değildir. ${ }^{23}$ Hatırlanacağı üzere benzer politika, 19. yüzyıl ortalarında İngiltere'ye karşı Çarlık tarafından takip edilmiş; Çarlar, İngiltere' yi Karadeniz'de görmemek için Boğazların kendi savaş gemilerine dahi kapalı olmasını kabul etmişti.

Tonaj sınırlarını aşan hastane gemilerinin yerine 22 Ağustos’ta, destroyer sınıfı USS McFaul, sahil güvenlik gemisi USS Dallas ve Altıncı Filo'nun komuta gemisi USS Mount Whitney'in Montrö hükümlerine uygun olarak Boğazlardan Karadeniz'e çıkmasına izin verildi. Aynı tarihte; ABD, İspanya, Almanya ve Polonya'ya ait dört NATO firkateyni tatbikat için Karadeniz'deydi. Üç Amerikan gemisinin girişiyle Karadeniz'de sahildar olmayan ülke gemisi sayısı yedi oluyordu. Buna karşın Montrö sahildar olmayan ülkelere ait gemi tonajını azami 45.000 tonla sınırlandırdığından ABD ve NATO için Karadeniz'de Rusya'ya karşı etkili ve caydırıcı bir güç oluşturmak olanaksızdır. RF'nin Karadeniz güvenliğinin anahtarı Türkiye'nin Montrö kurallarını geniş yorumlamayıp, sıkı bir şekilde uygulamasına bağlıdır. Ankara Montrö’yü tartışmaya açmamak için kurallara uyma konusunda kararlı bir tutum sergiledi. $\mathrm{Bu}$ sayede Gürcistan krizi iki ülke arasında önemli bir soruna neden olmadan atlatılabildi.

Kriz esnasında deniz yoluyla taşınan yardım bütün yardımın \%10’u kadardır. Amerikan Hükümeti’nin Boğazlardan geçişte 1srarının gereksizliği ya da iyi niyetten yoksunluğu açıkça görülmektedir. Gürcistan krizi, ABD ile Rusya arasında uzun süredir Kafkaslar, Balkanlar ve Karadeniz'de yaşanan hâkimiyet alanı paylaşım mücadelesinin sonucunda patlak vermiştir. Rusya, Montrö'nün ilgili hükümlerinden yararlanarak ABD'nin Karadeniz ve Kafkaslar'daki hamlelerini engellemeyi amaçlamıştır. Bu politikanın uygulanabilmesi Türkiye'nin tutumuna bağlıdır. İkinci kriz, Amerikan gemilerinin Karadeniz'de kalma süreleriyle ilgili olarak ortaya çıktı. Amerikan gemileri 21 günlük süre dolmasına rağmen Karadeniz'den çıkma konusunda titiz davranmayınca Rusya, gemilerin Montrö limitleri içinde Karadeniz'den çıkmasının Türkiye'nin sorumluluğunda olduğunu bildirdi.

22 Deniz Bölükbaşı, Dışişleri İskelesi, Dışişleri’nde 34 Yıl, Doğan Kitap, İstanbul 2011, s. 209.

23 Deborah Sanders, Maritime Power in the Black Sea, Ashgate Publishing Limited, UK, 2014. s. $80-81$. 
Moskova'nın isteği askeri olarak da dile getirildi. Rus Genelkurmay Başkan Vekili Anatoly Nogovitsyn, Eylül ayında yaptığı konuşmada Karadeniz'e giren NATO savaş gemilerinin Rus güvenliği için esaslı bir tehdit olduğunu, Amerikan gemilerinin Petersburg'a kadar Rus hedeflerini vurabilecek nükleer başlıklar taşıdıklarını; 21 gün sınırına uygun davranılmasının Türkiye'nin sorumluluğunda bulunduğunu bir kez daha tekrarladı. ${ }^{24}$ Montrö, 20 yıllığına imzalanmış bir sözleşmedir. Müzakereler esnasında İngiliz heyeti 50 yıllık bir sözleşme imzalanmasını teklif etmişti. Uluslararası bir sözleşme için 1936 y1lında çok uzun addedilen bu süre, bugün ikiye katlanmak üzeredir. Teknolojik gelişmeler karşısında yetersiz kalan Montrö halen yürürlüktedir. Montrö'nün yetersizliği Türkiye tarafindan oluşturulan ara hukuk kuralları ve esnek yaklaşımla çözümlenebilmektedir. Bu sayede ve uluslararası siyasi dengenin oluşturduğu sistem vasıtasıyla Sözleşme'nin yürürlüğü devam etmektedir. Buna karşın, şartlar değiştiğinde Montrö tartışmaya açılamayacak bir metin değildir. Montrö'ye göre ABD'nin Karadeniz'de bulundurabileceği savaş gemisi sayısı sınırlı olduğundan 2017 yılında ABD, Gürcistan'ın Poti şehrinde bir deniz üssü kurup, bu sayede Montrö'nün arkasından dolaşabilmek için girişimlerde bulunmaya başladı. ${ }^{25} \mathrm{Bu}$ girişimlerden henüz sonuç alınamamıştır. Rusya ise, Suriye krizi sayesinde tekrar Doğu Akdeniz'de Sovyet dönemi hegemon politikalara dönüş yapmıştır.

Gürcistan'ın kendi toprağı saydığı fakat yerel halkın self-determinasyon isteği nedeniyle tartışmalı Özerk Cumhuriyet Güney Osetya krizi Karadeniz'de ilk ciddi Rus, ABD cepheleşmesi olduğu kadar Soğuk Savaş sonrasında Türk Boğazları geçiş rejimiyle ilgili ilk ciddi krizdir. Rusya, Amerika ile Batı ekseninde hareket eden Tiflis'e karşı Güney Osetya ve Abhazya özerk cumhuriyetlerinin ayrılıkçı taleplerini desteklemektedir. Bu nedenle Güney Osetya krizi, Rusya'ya Montrö'nün ulusal güvenliği ve Karadeniz'deki varlığı için yaşamsal önemde olduğunu göstermiştir. Türkiye, ise Boğazları kontrol ettiğinden, kendisini doğrudan ilgili olmadığı bir krizin içinde bulmuştur. Montrö, her ne kadar sorumluluk yüklese de, sağladığı makro düzeydeki geniş yorum hakkı, Sözleşme'nin Türkiye için de vazgeçilmez olduğunun kanıtıdır. Bu nedenle Soğuk Savaş sonrasından günümüze kadar geçen sürede Suriye krizinde olduğu gibi esaslı anlaşmazlıklara rağmen ne Ankara ne de Rusya Montrö'yü tartışmaya açmamayı yeğlemektedir.

Bölge dışı aktörlerin Karadeniz'e müdahale isteği, NATO'nun Karadeniz'de varlık gösterme arzusu Türk Boğazları'nı ve Montrö Sözleşmesi'ni yeniden gündeme taşıdı. NATO, deniz gücünü artırabilmek amacıyla 2011 yllında İttifak Deniz Stratejisi/Alliance Maritime Strategy (AMS), adlı yeni bir

24 https://www.haberler.com/rusya-genelkurmay-baskanligi-guney-osetya-da-haberi/(30 May1s 2020 tarihinde erişildi).

25 https://www.denizhaber.net/abd-gurcistana-deniz-ussu-kuracak-haber-15262.htm (30 Mayls 2020 tarihinde erişildi). 
uygulama başlatmıştı. ${ }^{26} \mathrm{Bu}$ politikanın uygulanmasında aktif rol alan Türkiye, Karadeniz'de tehdit değil fakat yüksek risklerin bulunduğu görüşündeydi. Ankara tarafindan gerek Suriye krizini yönetebilmek gerekse Karadeniz'deki çıkarları garanti altına alabilmeye yönelik politikalar uygulanmaya çalışılırken Türk-Rus ilişkilerinde son yılların en derin krizi baş gösterdi.

Suriye semalarında uçup, Türk sınırındaki Türkmen köylerini bombalayan bir Rus savaş uçağı 24 Kasım 2015 tarihinde Türkiye-Suriye hududunda sınır ihlali yapması nedeniyle Türk jetleri tarafından düşürüldü. Dört ay önce, 2015 y1lı Temmuz ayında Rusya, NATO planlamalarına cevap olarak, denizlerde etkin rekabet yürütebilmek için revize edilmiş Deniz Doktrini'ni yürürlüğe koymuştu. Karadeniz ile Doğu Akdeniz entegre bir yaklaşımla yeni deniz doktrininin güney ayağını oluşturuyordu. ${ }^{27}$ Önemli kısmı Boğazlardan nakledilen Petrol ve doğalgaz ihracatı uzun süredir ordusunu ve deniz gücünü modernize etmek isteyen Rusya için vazgeçilemez finans kaynaklarıdır. Yeni doktrinin uygulanmasında aynı anda hem fosil yakıtların geçiş güzergâhı hem de Karadeniz güvenliğinin kapısı olmaları nedeniyle Türk Boğazlar alternatifsiz bir statüye sahiptirler. Yeni deniz doktrini 2010 yılında başlatılan silahlanma programının parçası olarak 2020 yılına kadar Rus deniz gücünün modernize edilip, kapasite ve sayı artırılarak, nükleer güçle çalışan denizaltı takviyesiyle birlikte etkin bir kuvvete dönüşmesini hedeflemekteydi. ${ }^{28} \mathrm{Bu}$ hedefe büyük oranda ulaşılmıştır.

Krize neden olan hadise kaçınılmaz olarak kamuoyunda Boğazlar geçiş rejimini ve Montrö Boğazlar Sözleşmesi’ni gündeme getirdi. Çünkü Rusya, Boğazları Suriye iç savaşına rejim lehinde müdahale edip, Doğu Akdeniz'deki gücünü kuvvetlendirmek için aktif olarak kullanıyordu. Uçak krizinden kısa süre sonra 158 numaralı Rus savaş gemisi Boğazlardan geçerken, güvertesinde omuzunda karadan havaya atılan füze taşıyan bir Rus askeri fotoğrafland. Geminin uçaksavar mekanizmaları da harekete hazır bekletilmekteydi. Omuzdan atılan füzeyle İstanbul'a zarar verilemeyeceğine, geçişine izin verilen Rus savaş gemisine Boğazlarda herhangi bir tehdit olmadığına göre, füze gösterisinin amacı Türkiye'ye gözdağı vermekti. Aynı sınıf Rus füzesi ile birkaç ay sonra PKK'lı teröristler güneydoğuda bir Türk helikopterini düşürdüler.

Türk-Rus krizi esnasında NATO, tarafsız uluslararası bir sivil toplum kuruluşu, kanarya sevenler derneği umursamazlığıyla sanki kendisinin hiçbir şekilde bulaşmak istemediği bir çatışma yaşanıyormuş gibi; Rus uçağının sınır ihlali yaptığını teyit edip, iki tarafa itidal çağrısında bulundu. Yaklaşık bir buçuk y1l süren kriz süresince NATO tarafindan Türkiye'yi askeri olarak destekleyen herhangi somut bir girişimde bulunulmadı. Bu durum, NATO'nun 1950 yilındaki savunma konseptinden ayrılmadığını göstermesi açısından dikkate değerdir.

26 Steven Horrell vd., "Updating NATO’s Maritime Strategy”, Atlantic Council, Washington 2016, s. 1.

27 Horrell vd., a.g.m., s. 2.

28 Gaber, a.g.m., s. 206. 
Büyük oranda Türkiye'nin sağlayacağı olanaklarla Karadeniz'de Rus meydan okumasına karşılık vermek isteyen NATO, aynı hassasiyeti Türkiye'nin çıkarlarının korunmasında göstermemektedir.

\section{Karadeniz'de Artan Rus Varlığı}

Soğuk Savaş döneminin Karadeniz'deki iki başat aktörü Türkiye ve RF'nin Karadeniz Havzası'ndaki çıkarları bazı kritik noktalarda örtüşmektedir. Örneğin her iki devlet de Montrö'yü tartışmaya açmaktan ve Karadeniz'de uzun süredir var olan statükonun bozulmasından kaçınmaktadır. Rekabet içinde işbirliğini teşvik eder şekilde Türkiye, $R F, A B D$ ve $A B$ Karadeniz Havzası'nda yükselebilecek olası radikal akımlardan tehdit algılamaktadır. Bunlara karşın Türkiye, RF'nin Karadeniz Havzası'ndaki agresif tutumundan, Kafkaslar'da AKKA limitlerini aşan Rus askeri varlı̆̆ından ve Karadeniz'de olası Rus hegemonyasından hoşnut değildir. Bu nedenle dengeli bir siyasetle NATO şemsiyesi altında $\mathrm{ABD}$ ve $\mathrm{AB}$ 'nin Havza'da Rus gücünü dengelemesi Türkiye tarafından desteklenmekte buna karşın güç dengesinin $A B D$ ve $A B$ lehine dönmesi de istenmemektedir.

Moskova, 9/11 Saldırıları sonrası ABD'nin Karadeniz Havzası'nda artan varlığından rahatsız oluyordu. Söz konusu hoşnutsuzluğu tetikleyecek şekilde NATO 2017 yılı sonunda yedinci genişlemesini gerçekleştirerek Rusya'nın Balkanlar'daki güvenlik derinliğini Ukrayna hariç bünyesine aldı. Böylece Karadeniz'in batı yakası NATO etki alanına girmiş oldu. Aynı yıl, Karadeniz'deki donanma varlığının artırılmasına karar verildi. ${ }^{29}$ Ukrayna ve Gürcistan'ın da NATO'ya katılmayı istedikleri bilindiğinden sekizinci genişleme kaçınılmaz olarak Karadeniz'de Rusya ve NATO üyeleri şeklinde bir askeri denge oluşturacaktı. Sivastopol Limanı Rusya'nın Karadeniz'e ve dolayısıyla Doğu Akdeniz'e açılan deniz koridorunun üs noktasıdır. Bu nedenle Sivastopol'un güvenliği Ukrayna'da konuşlanacak olası bir NATO gücü karşısında sorunlu hale gelebilecekti.

Gerek AB gerekse ABD, 1990'lı ylların ortalarından itibaren Karadeniz Havzası'nın Ortadoğu enerji kaynaklarına güçlü alternatif oluşturabileceğini fark etmişlerdir. RF ile doğrudan cepheleşmeden, fakat RF'nin özellikle $A B$ ve ABD çıkar alanlarında etkinlik kurmasını engellemeye yönelik politikalar uygulamaya konuldu. Karadeniz Havzası'nın iç hilal kısmının açık denizlerle yegâne bağlantısı Boğazları kontrol eden Türkiye'nin Karadeniz Havzası'ndaki öncelikleri bu alanlarda ABD ile benzerdi. Buna karşın söz konusu politikaların daima uyuştuğunu söylemek güçtür. Türkiye de Karadeniz güvenliğine, Havza ülkelerinde demokratik yönetimlerin iktidarda bulunması ve enerji nakil hatlarının Anadolu üzerinden geçerek Avrupa pazarlarına ulaşmasına yönelik politikalar üretmektedir.

29 New Strategy Center Policy Paper-2019, "The NATO and new Military Posture in the Black Sea", https://newstrategycenter.ro/wp-content/uploads/2019/02/Policy-Paper-New-StrategyCenter-Centro-Studi-Internazionali2019.pdf(01 Haziran 2020 tarihinde erişildi). s. 18-19. 
Karadeniz'e yönelik ABD politikaları şu şekilde formüle edilebilir: (1) Bir bütün olarak Rusya'nın iç ve dış Karadeniz Havzası'nda yeniden ABD çıkarlarına meydan okuyabilecek düzeyde güç kazanmasının engellenmesi (2) İç ve dış Havza'da $\mathrm{AB}$ ve $\mathrm{ABD}$ güvenliğini tehdit edebilecek radikal, köktendinci akımların yerinde engellenip bulunduğu alanda izole edilmesi (3) Hazar ve Türkistan bölgesinden Avrupa ve ABD pazarlarına gerek petrol gerekse doğalgaz akışının garanti edilip enerji güvenliğinin sağlanması (4) ABD çıkarlarını tehdit etmeyecek bölgesel örgütlenmelerin desteklenmesi (5) Önceliğin demokrasiye değil güvenlikçi politikalara verilip, bölgedeki $\mathrm{ABD}$ etkisinin artırılması (6) Karadeniz'de mümkün olduğu kadar fazla deniz gücü bulundurabilmek için $\mathrm{ABD}$ yörüngesinden çıkmayacağından emin olunan devletlerde deniz ve kara üsleri kurulması.

Washington'un ilk önceliği enerji olmasına rağmen, üç kavram birbiriyle bağlantılı kombine politikalara ihtiyaç duymaktadır. Nitekim Havza'da demokratik yönetimler kurulup, RF'nin alan genişletme siyasetine alternatifler üretilip, liberal politikalarla radikal akımların taraftar kazanması engellenmeden enerji güvenliğinin sağlanması olanaksızdır. Söz konusu politikaların uygulanmasında Boğazlardaki askeri geçiş kısıtlamaları Washington'un önündeki en önemli engeldir.

Daha önce de ifade edildiği gibi Karadeniz'in kilidi Türk Boğazları, anahtarıysa Montrö Boğazlar Sözleşmesi'dir. Montrö, imzalandıktan sonra; II. Dünya Savaşı, atom ve hidrojen bombalarıla nükleer enerjinin keşfi, İsrail'in kuruluşu ve Ortadoğu'nun savaş sarmalına savrulması, daha sonra SSCB ve Yugoslavya'nın dağılması, AB'nin Balkanlar'a doğru genişlemesi, Rusya'nın Kırım'ı ilhakı ve Suriye'deki iç savaş delaletiyle Doğu Akdeniz'de artan Rus hükümranlığı, gemicilik teknolojisindeki hızlı ilerleme gibi dünya ve bölge politikasını yakından etkileyecek esaslı gelişmeler gerçekleşmiştir. Buna karşın Montrö’nün geçerlilik süresi 64 yıl önce dolmasına, Sözleşme son teknolojik gelişmeler ve gemi yapım sanayi karşısında yetersiz kalmasına rağmen, halen yürürlükte olan bir Sözleşme'dir.

$\mathrm{Bu}$ durumun en temel nedeni Türk Boğazları'nın sui jeneris konumu, imzacılar ile imzacı olmayan devletlerin istekliliği ve Karadeniz'e sahildar devletlerin çıkarlarını koruyabilecek en uygun Sözleşme'nin Montrö olmasından kaynaklanmaktadır. Sözleşme'nin sağladığı avantajlar halen yetersizliklerinden fazladır. Her ne kadar yeni bir konferans toplanıp, Rusya'nın da işbirliğiyle Montrö'nün eksikliklerinin giderilip; kılavuz kaptan almanın zorunlu hale getirilmesi, tonajların son gelişmelere göre yeniden düzenlenmesi, tehlikeli yakıt ve nükleer kaçakçılıkla ilgili daha katı tedbirler alınması sağlanabilecek olsa da, böyle bir konferansta sahildar olmayan ülkelerin Karadeniz'e geçişine sınırlama koyan hükümlerinin de tartışmaya açılarak uzlaşının bloke edilebilmesi yüksek olasılıktır. Bu durumda Boğazlarda BMDHS yürürlüğe girecektir. Boğazlar geçişinde sahildar olmayan ülkelere de Sevr ve Lozan benzeri serbest hava sahası dahil sınırsız geçiş hakkı sağlayabilecek BMDHS hem Türkiye'nin hem de Rusya'nın çıkarlarına aykırıdır. 
Montrö'nün sürdürülebilirliğinin diğer nedeni Türkiye'nin uygulamada esnek bir tutum takınarak Sözleşme'nin yetersizliklerinin seyrüseferi aksatmasına ya da mağduriyetler yaratmasına engel olmasıdır. Yunanistan gibi devletler bu uygulamaya keyfilik suçlamasında bulunsalar da, gelişmelerin gerisinde kalan Montrö'nün başta şekilde uygulanması olanaksızdır. Rusya'nın Karadeniz'deki, Ukrayna, Romanya, Gürcistan, Polonya gibi ABD yanlısı hükümetleri hizaya getirmek için uygulamaya koyduğu agresif politika üzerine ABD için Karadeniz'e istihbarat, hastane gemisi adı altında müttefik hükümetlere destek ve Rusya'nın askeri gücünü dengeleyebilecek askeri gemi sokmak esaslı bir ihtiyaç haline gelmiştir. Boğazlardan geçen bir ABD harp gemisinin, sahildar olmayan diğer ülke gemileriyle birlikte azami 45.000 tonu geçemeyecek olması ABD'nin Karadeniz'deki operasyonel olanaklarını kısıtlayan önemli bir kuraldır. Diğer sorun 21 günle sınırlanmış süredir.

Karadeniz'de Rusya ile birlikte üç NATO üyesi, Türkiye, Bulgaristan ve Romanya'nın da kıyısı bulunmaktadır. Bu nedenle Karadeniz ve Boğazlardaki Rus politikaları NATO'yu da doğrudan etkilemektedir. Rusya ise Karadeniz Havzası'nı tarihsel bir içgüdüyle kendi lebersnaum benzeri yaşam ve doğal yayılma alanı olarak görmektedir. Varşova'da 2016 yılı Temmuz ayında toplanan NATO zirvesinde, uçak krizindeki pasif tutumun aksine Rusya'nın Karadeniz ve kıyısındaki son faaliyetlerinin bölge güvenliğini tehlikeye attığına dikkat çekildi. ${ }^{30}$ Rusya'nın son 10 yılda Karadeniz ve çevresindeki etkinliğini artırarak küresel aktör statüsüne çıkmaya çalıştığı böylece NATO gündemi arasında yer aldı. ${ }^{31}$

Soğuk Savaş döneminde Karadeniz, Montrö’nün sağladığg kapalılık sayesinde Sovyetler ve Türkiye tarafından mare mostrum olarak kabul edilmişti. Bu nedenle Soğuk Savaş'tan günümüze Türkiye ve Sovyetler'in halef devleti RF Karadeniz'deki statükonun korunmasına öncelik veren bir politikaya taraftırlar. Türkiye ile Rusya arasında Osmanlı-Çarlık ilişkilerinden farklı olarak, II. Dünya Savaşı sonrası Stalin'in Boğazlar'dan üs talebiyle çıkan kriz haricinde ne Sovyet döneminde ne de Sovyet sonrasında Karadeniz yetki alanları paylaşımında sıcak çatışmaya varabilecek sorunlar yaşanmamıştır. Özellikle RF, statükonun kendi aleyhine bozulmasına razı olmayacağını Gürcistan ve Ukrayna krizlerinde tereddüt etmeden orantısız güç kullanımını devreye sokarak göstermiştir.

Anti-Access/Area Denial (A2/AD) askeri terminolojide bir ülkenin özellikle denize caydırıcı silah sistemleri yerleştirip bu sahaya diğer devletlerin girişine engel olduğu bölge anlamına gelmektedir. A2/AD bölgelerde gemi/uçak savar füze sistemleri, ileri uçak gemileri, denizaltılar, siber saldırı sistemleri vb. bulunabilir. Yukarıda da ifade edildiği gibi RF, yeni askeri doktrini kapsamında

30 Warsaw Summit Communiqué, https://www.nato.int/cps/en/natohq/official_texts_133169. htm (28 Mayıs 2018 tarihinde erişildi).

31 Pavel Anastasov, The Black Sea region: a critical intersection, NATO Review Magazine, 25 May 2018. https://www.nato.int/docu/review/2018/Also-in-2018/the-black-sea-region-acritical-intersection-nato-security/EN/index.htm (28 Mayıs 2018 tarihinde erişildi). 
2010 yılından itibaren Karadeniz Donanması'nı yeni bir programla güçlendirmeye başlamıştı. Bu kapsamda 2015 ve 2016 yıllarında altı yeni kylo sınıfı denizaltı Rusya'nın sofistike A2/AD bölgesi Karadeniz donanmasına eklendi. ${ }^{32}$ Kırım'ın ilhakı sonrasında Rusya'nın Karadeniz Donanması'nı genişletip güçlendirmesi Türkiye başta gelmek üzere bölge ülkelerini tedirgin etmeye yetecek bir durumdur. Buna karşın RF için önemli bir kısıtlılık mevcuttur. Zira Boğazlar Rus donanmasının Karadeniz dışında hareket kabiliyetinde anahtar rolü oynayabilecek bir konumdadırlar. Montrö yürürlükte olduğu sürece Karadeniz Rusya için güvenlik alanı, Boğazlar Türkiye için kontrol edilebilir geçişlerdir. Aksi durum öngörülemeyecek çok sayıda soruna neden olabilecektir.

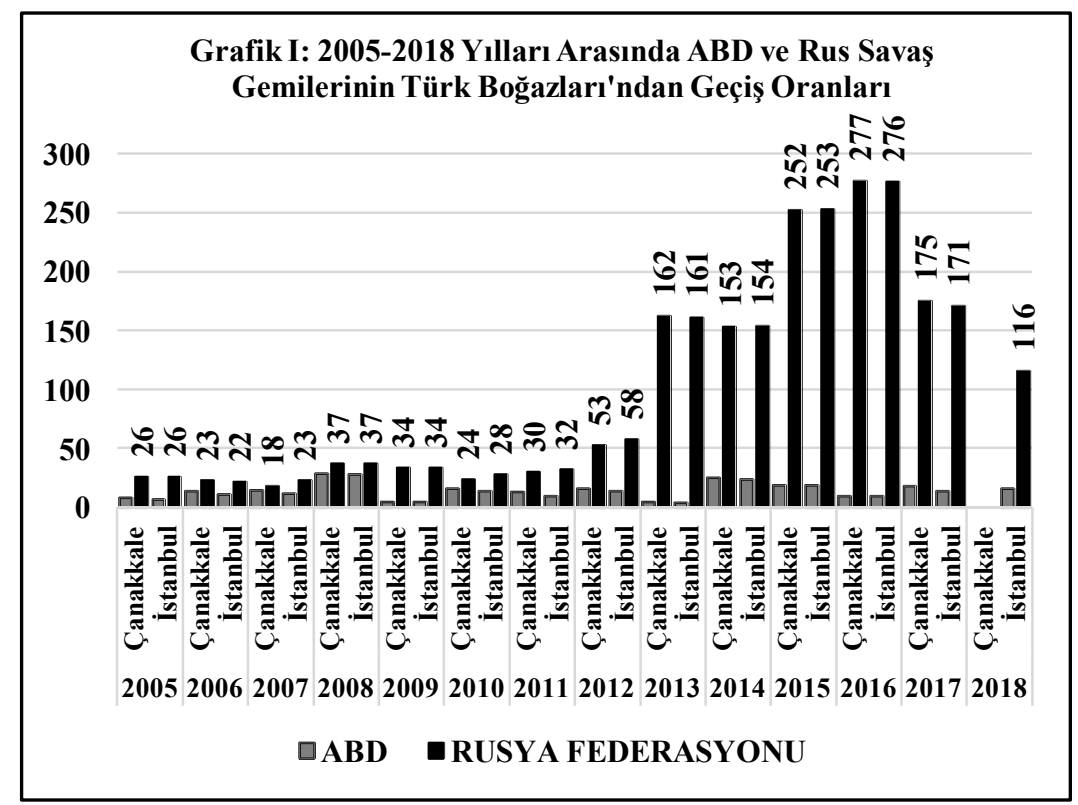

Kırım'ın ilhakının Türkiye dahil NATO üyeleri tarafından tanınmaması Rusya'nın gelecekte Sivastopol'daki donanma varlığını olumsuz etkileyebilecektir. Rusya ile cepheleşmek istemeyen ABD, Balkanlar'daki ve Batı Karadeniz kıyılarındaki kazanımlarını yeterli sayarak şimdilik NATO’nun sekizinci genişlemesine soğuk bakmaktadır. Güneyden çevrelenme endişesi yaşayan Moskova NATO tarafından gerçekleştirilecek olası sekizinci genişlemenin doğrudan kendisine tehdit olarak algılanacağını birkaç kez ifade etmiştir. ${ }^{33} \mathrm{Bu}$ tür bir gelişme kaçınılmaz olarak hem Karadeniz'in statüsü hem de Boğazlar'dan geçiş rejimiyle doğrudan ilintili yeni bir statüko yaratacaktır.

Rus Karadeniz stratejisi: (1) Mağlup olunan I.; açık şehirlerin yok edilmesi pahasına kazanılan II. Çeçenistan savaşları (2) Gürcistan'a askeri müdahale

\footnotetext{
32 Anastasov, a.g.m., (28 Mayıs 2018 tarihinde erişildi).

33 http://tass.ru/politika/4323815 (14 Aralık 2018 tarihinde erişildi).
} 
(3) Kırım'ın ilhakı (4) Ukrayna'da iç karışıklık çıkartılıp bu ülkenin Batı Bloku ile entegrasyonunun engellenmesi (5) Karadeniz'de tahkim edilen deniz gücü yapılanması sayesinde Suriye krizi kullanılarak Sovyetler'in 1959 y1lı sonras1 Ortadoğu'da güçlü varlık göstermeye yönelik politikalarının tekrar uygulamaya konulması (6) Libya'da meşruiyeti olmayan Asi Hafter güçlerinin desteklenip, Yakın Çevre Doktrini'nin gerçekleştirilebilmesi için çapın genişletilmesini hedeflemektedir. Söz konusu girişimler Kırım'ın ilhakı sonrasında Rus deniz hâkimiyeti doğrultusunda ileri adımların hayata geçirilmesini sağlama çalışmalarının ikinci aşamasıdır.

Bütün bu politikalar Moskova'nın kara hinterlandını içine alan Büyük Karadeniz Havzası kavramsallaştırmasını çok iyi bir şekilde analiz ettiğini göstermektedir. Cezayir'e ait Merselkebir deniz üssünün bir zamanlar Sovyetler tarafindan Pyadyy Eskadra [Beşinci Filo] faaliyetleri kapsamında kullanıldığ unutulmamalıdır. ${ }^{34}$ Karadeniz'de yeterli güce ulaştığına karar veren Moskova, tarihsel bir güdüyle vakit geçirmeden yönünü Doğu Akdeniz'e çevirdi. Türkiye ile yaşanan Uçak krizi sonrasında Rus savaş gemilerinin Boğazlardan geçiş oranı hızla arttı. Türk Boğazları'ndan: 2014 yılında 222; 2015 yılında 308; 2016 yılında 348 ve 2017 yılında bir önceki yılla aynı miktarda 348 savaş gemisi geçiş yaptı. Boğazlardan geçen savaş gemilerinin 2016 yılında 171'i; 2017 yılında ise 116'si, diğer bir ifadeyle hemen hemen yarıya yakın yüksek miktarı Rusya'ya aittir. Rus, Amerikan savaş gemilerinin Boğazlardan geçiş oranları karşılaştırmalı olarak grafik 1'de gösterilmiştir. ${ }^{35}$

Karadeniz'de artan İngiliz, Amerikan donanma aktivitelerini ve üst kurma faaliyetlerini yakından takip edip, notalar vererek sürekli protesto eden Kremlin, 2018 yılında Suriye'deki üslerine Karadeniz'den geçirdiği savaş gemileriyle malzeme taşımayı sürdürdü. Hatta Karadeniz'deki varlığını güçlendirebilmek için buradaki donamasına takviye yapmaya başladı. ABD ise NATO olanak ve kabiliyetlerini kullanarak, Romanya ve Türkiye gibi tonaj sınırlamasına tabi olmayan sahildar ülkeler vasitasıyla Karadeniz'deki dengeyi kendi lehine dönüştürme çalışmalarına hız verdi. NATO politikalarının önündeki en önemli kısıtlılık Montrö'nün amir hükümleridir. Montrö yükümlülüklerinin arkasından dolaşmayı amaçlayan ABD, İngiltere eşgüdümünde 2017 yılında Ukrayna ile birlikte gerçekleștirilen Sea Breeze tatbikatı sonrasında 2018 yılında Dinyeper (Özi) Nehri kıyısında Oşakiv'de (tarihi Özi Kenti) bir deniz operasyon merkezi kuracağını açıkladı. Ukrayna ile sorunlar yaşayan Rusya, deniz üssü kurmak niyetli olmanın yanında nabız yoklama amaçlı, açıklamayı şiddetle protesto etti. ${ }^{36}$ Üs planının önemi 2018 yılı Kasım ayında yaşanan Kerç Boğazı krizinde açıkça ortaya çıktı.

34 TBMM TD, B. 13, O. 1.04 Aralık 1968, s. 356-358.

35 Ulaştırma Denizcilik ve Haberleşme Bakanlı̆̆ yayınlanmamış istatistikleri.

36 Ridvan Urcosta, "U.S. Advance and Russia's Deep Concerns: The Operations Center in Ochakiv", https://www.academia.edu/38869244/U.S._Advance_and_Russias_Deep_Concerns _The_Operations_Center_in_Ochakiv (23 Nisan 2020 tarihinde erişildi). 
Rusya ile Ukrayna arasında yaşanan Kırım anlaşmazlığı 2018 yılı Kasım ayı sonunda Kerç Boğazı'nda düşük çaplı bir çatışmaya dönüştü. NATO, Ukrayna'ya destek açıklarken ABD Ukrayna'yı Rus saldırganlığına karşı koruyabilmek için bir kez daha Karadeniz'e savaş gemisi sokmayı gündeme taşıdı. ABD, Karadeniz'e soktuğu gemilerin ya Türkiye'nin göz yummasıyla ya da gemilerin arıza yaptıkları bahanesiyle Karadeniz'deki Türk limanlarına sığınarak buradaki varlıklarını devam ettirmelerini arzuluyordu. Kremlin, Boğazlardan geçen gemilerin tonaj ve süre kontrolünü dikkatle izliyordu. Nitekim 2016 yılı sonunda RF Dışişleri Bakanı Sergey Lavrov, ihlallere dikkat çekerek, Gürcistan krizi esnasındaki tutumu tekrarlayıp, Boğazların sahibi Türkiye'nin Montrö'yü uygulamasını istedi. ${ }^{37}$

Kerç Boğazı krizi çok fazla büyümeden sona erdi. Bu esnada Suriye krizinin evrildiği çatışmacı yeni aşama dikkatleri güçlü bir şekilde Türk Boğazları'na çevirdi. RF'nin Suriye krizi vasıtasıyla Doğu Akdeniz'de hegemon bir güç olarak tekrar varlık gösterme girişimleri Boğazlardan Rus askeri gemi geçişlerine de doğrudan yansımıştır. Grafik II'de Rus savaş gemilerinin yıllara göre Boğazlardan geçiş yoğunluğu görülmektedir. ${ }^{38}$

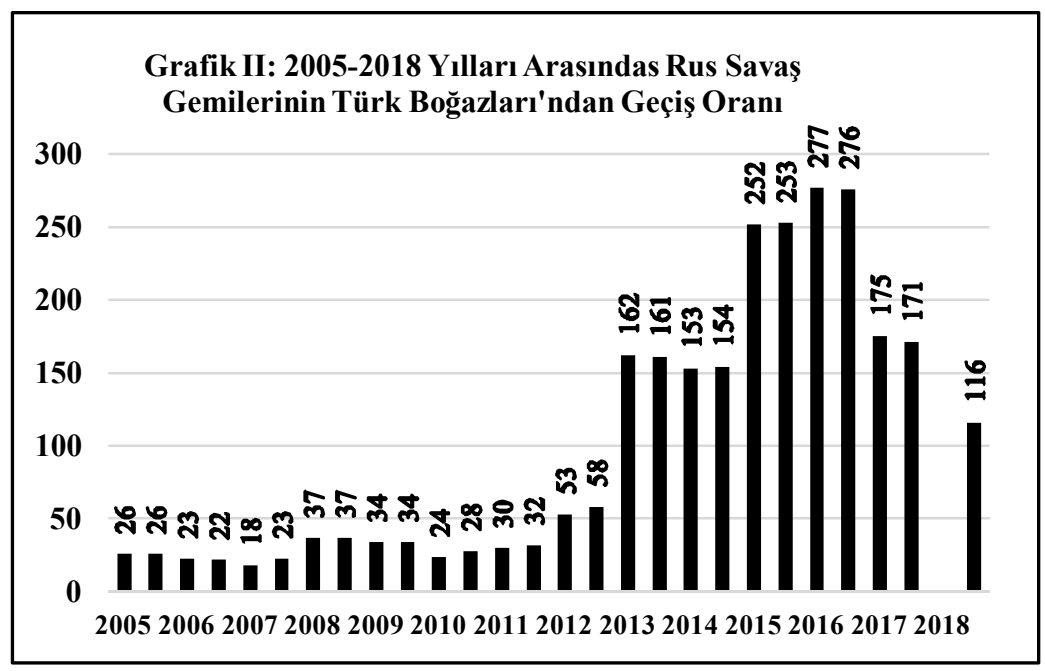

Rusya Federasyonu savaş gemilerinin Türk Boğazları'ndan geçiş rakamındaki artış matematiksel olarak yüksek olmanın yanında, geçişlerdeki hızlı artış siyasi açıdan esaslı sonuçlar doğurabilecek nitelikte olup, Doğu Akdeniz’e yönelik politikayı somut olarak ortaya koymaktadır. Geçişlerin yoğunluğu Bölge politikalarını derinden etkileyen makro düzeyde politik, askeri ve ekonomik sonuçlara sebebiyet verebilecektir. Özellikle Suriye krizi patlak verdikten sonra Rus savaş gemilerinin geçişlerinde dört kata varan artış görülmektedir. Bu

37 Milliyet, "Rusya'dan Boğaz Uyarısı", 14 Aralık 2016.

38 Ulaştırma Denizcilik ve Haberleşme Bakanlığı yayınlanmamış istatistikleri. 
dönemde Boğazlardan hemen hemen her gün en az bir Rus savaş gemisi geçmiştir.

Rus savaş gemisi geçişindeki diğer dikkat çekici durum, iki yönlü geçişler arasındaki yakınlıktır. Söz konusu korelasyon Rusya'nın Doğu Akdeniz'de kendi toprakları dışındaki tek deniz üssü olan Tartus üssü ile Sivastopol'daki donanma üssü arasında bir tür kesintisiz seyrüsefer hattı kurduğunu göstermektedir. Çarlık döneminde 1798 yılında Napolyon Savaşları esnasında, ${ }^{39} 1833$ yılında Asi Vali Mehmet Ali Paşa krizi esnasında ve 1878 yılı sonrasında Filotte Volonter Gönüllü Donanması adı altında Karadeniz ile Doğu Akdeniz arasında kısa süreli deniz hatları oluşturabilen Rusya, Montrö sayesinde söz konusu arzusunu kesintisiz olarak elde edebilmiştir. ${ }^{40} \mathrm{Bu}$ saptamayı teyit eder şekilde, daha önce de ifade edildiği gibi Boğazlardan son 13 yılda geçen toplam savaş gemilerinin hemen hemen yarısının RF'ye ait olduğu görülmektedir. Grafik I'de $A B D$ ve Rus savaş gemilerinin geçişi karşılaştırmalı olarak gösterilmiştir. ABD geçişlerinde çok fazla dalgalanma olmamasına karşın Rus geçişleri kriz dönemlerinde hızla artış göstermektedir.

Eldeki verilerin aritmetik hesaplamasıyla son 13 yılda 195 ortalama ile hemen her iki günde bir Boğazlardan bir Rus savaş gemisi geçtiğini saptamak olasıdır. Bu rakam aynı dönemde yıllık kayıtlı geçiş ortalaması 122 olan Türk Donanması'nın geçişinden bile 1/3 oranında daha yüksektir. Boğazlarla ilgili son günlerde gündemi meşgul eden diğer tartışma İstanbul Boğazı'na paralel yeni bir kanal yapılması düşüncesidir. Uygulamaya konulabilirse Kanal İstanbul projesinin Montrö’ye aykırılığı gibi bir durum söz konusu olamaz. Nitekim, Boğazlar deniz ve kara ülkesiyle Türkiye'nin mülkünde olduğu için Türk toprağının herhangi bir yerinden kanal açılması, bu kanalda uygulanacak geçiş rejimi tamamen Türkiye'nin yetkisindedir. Buna karşın Montrö Boğazlar geçiş rejiminin Kanal'a da aynen uygulanması zorunluluktur. Zira, Montrö sadece Boğazlar geçişini değil, Karadeniz'in statüsünü de belirlediğinden Kanal yoluyla bu kuralın ihlali ya da delinmesi uluslararası hukuka aykırı bir durum yaratıp haklı itirazlara sebebiyet verebilecektir.

\section{Sonuç}

Karadeniz, tarih boyunca iç ve diş çap hinterlandı ile birlikte değerlendirilmiştir. Antik dönemden günümüze Karadeniz büyük bir su kütlesi olmanın ötesinde çevre havzanın kontrol edilebileceği devasa bir güç alanı olarak telakki edilmiştir. Bu durum kaçınılmaz olarak yakın ve uzak aktörlerin Havza' da varlık gösterme arzusunu tetiklemiştir. Enerji kaynaklarının geçiş güzergâhında yer alması yüzlerce yıl kadim ticaret yollarını Avrupa'ya ulaştıran Karadeniz'in öneminde çarpan etkisi yapmıştır. Talep sahibi her geçen gün artan etkinlik kurma faaliyetleri kaçınılmaz olarak krizleri de beraberinde getirmiştir.

\footnotetext{
39 BOA, HAT.00033.01586.0001.

40 BOA, Y.PRK.TKM.00023.00002.002.001.
} 
Soğuk Savaşı sonrası güç mücadelesinin Karadeniz'in statüsünde ve geleceğinde belirsizliğe neden olduğu görülmektedir. Soğuk Savaş’ın bitmesinden hemen sonra Karadeniz'de var olan güç dengesi bozulmuştur. I. Dünya Savaşı öncesi dönem ile benzer olarak Karadeniz bölgesel olmanın ötesinde küresel çıkar çatışmalarının merkezi haline gelmiştir. Bu durum Soğuk Savaş sonrası şekillenen bloklar arasında adı konulmamış fakat lider söylem analizinde açıkça görülebilen bir güç mücadelesine neden olmuştur. Her ne kadar Soğuk Savaş'ın kaybeden tarafinı temsil etse de RF, yaşam alanı gördüğü Karadeniz'i ne paylaşmaya ne de burada yabancı güçler görmeye razıdır.

Soğuk Savaş sonrası dönemin en önemli sorunlarından birisi de Rusya'nın eski Çarlık/Sovyet hükümranlık alanını kontrol etmeyi, bu alanda etkinlik kurmayı amaçlayan irredendist politikalarıdır. Son dönem Amerikan hükümetleri tarafından Rusya'nın hegemon arzularını Kafkaslar, Türkistan bölgesinde hatta Suriye'de serbest bırakıp, Ortadoğu'ya Rus erişimini engelleyip, Amerikan çıkarları yaşamsal zarara uğramadığı sürece Rusya ile cepheleşmekten kaçınan bir politika takip edilmektedir. Amerikan'ın bu pasif tutumunun olumsuzluklarından ilk olarak Türkiye etkilenmektedir. ABD'nin Karadeniz'de istediği oranda güç bulundurması olanaksızdır. Bu durum Washington'u farklı arayışlara mecbur bırakmaktadır.

ABD’nin serbestçe deniz gücü sokamadığı yegâne açık su kütlesi Karadeniz'dir. Washington, AB'yi yanına alıp, NATO'nun imkân ve kabiliyetlerini kullanarak Karadeniz'deki statükoyu değiştirmeye isteklidir. Türkiye, Karadeniz'in kendi güvenliği için çarpan faktörünün farkındadır. Buna karşın bölgede çok fazla kudretli oyun kurucu olduğundan denge siyasetine dayalı bir dış politika yürütmekte, ne tür riskler barındıracağı belli olmayan maceracı girişimlerden uzak durulması yeğlenmektedir.

Karadeniz hâkimiyeti için uzun hazırlıklar sonrasında Kırım'ın ilhak edilip, Sivastopol üssünün ele geçirilmesi Karadeniz ve hinterlant havzadaki irredendist, tarih boyunca kuvvet siyasetine öncelik veren Rus dış politikasının Gürcistan krizi sonrasında Karadeniz'de kudret daralmasına razı olmayıp, yumuşak güç yerine gerektiğinde sert güç kullanımında tereddüt edilmeyeceğini gösteren ikinci offensive realist hareket olmuştur. Moskova, 2020 yılına kadar yaşanan krizlerde Montrö’yü tartışmaya açmaktan kesinlikle kaçınıp, Boğazların sahibinin ve Sözleşme'nin uygulayıcısının Türkiye olduğunu teyit etmiştir. Rusya'nın Montrö’ye verdiği esaslı önem ile Sözleşme’nin yetersiz kaldığı sivil alanlarda Boğazlar'da Türk iç hukukunun uygulanmasına çok fazla itiraz yöneltilmemesi statükonun korunmasına katkı sağlamaktadır. Mevcut şartlar altında Karadeniz'deki güç mücadelesi ve denge siyaseti eş zamanlı olarak sürdürülmek durumundadır. 


\section{KAYNAKLAR}

\section{Türkiye Cumhuriyeti Cumhurbaşkanlığı Devlet Arşivleri (BCA)}

$B C A, 030.18 .01 .01 .012 .66 .9$. 04/01/1924.

$B C A, 080.18 .01 .01 .012 .63 .7 .31 / 12 / 1924$.

$B C A, 301812.373 .147 .11 .13 / 06 / 1978$.

$B C A, 301812.377 .208 .17 .15 / 02 / 1979$.

$B C A, 301812.450 .470 .6 .03 / 05 / 1982$.

$B O A$, HAT. 00033.01586.0001.

$B O A$, HR. SYS. 02295.00002.001. 17/01/1918.

BOA, Y.PRK.TKM.00023.00002.002.001.

\section{2. İnternet Kaynakları}

Rusya Genelkurmay Başkanlığı: "Güney Osetya'da Düzeni Biz Sağlamazsak Kim Sağlayacak? https://www.haberler.com/rusya-genelkurmay-baskanligi-guneyosetya-da-haberi/ (30 Mayıs 2020 tarihinde erişildi).

$A B D$, Gürcistan'a deniz üssü kuracak, https://www.denizhaber.net/abdgurcistana-deniz-ussu-kuracak-haber-15262.htm (30 Mayıs 2020 tarihinde erişildi).

Karadeniz Deniz İsbirliği Görev Grubu, https://www.dzkk.tsk.tr/icerik.php? icerik_id=242\&dil=1\&blackseafor=1 (30 Mayıs 2020 tarihinde erişildi).

S.579 - Silk Road Strategy Act of 1999,

https://www.congress.gov/bill/106th-congress/senate-bill/579(30 Mayıs 2020 tarihinde erişildi).

New Strategy Center Policy Paper-2019, "Militarization in the Black Sea and Eastern Mediterranean Theatres, A new Challenge to NATO", https:// newstrategycenter.ro/wp-content/uploads/2019/02/Policy-Paper-New-StrategyCenter-Centro-Studi-Internazionali2019.pdf (01 Haziran 2020 tarihinde erişildi).

New Strategy Center Policy Paper-2019, "The NATO and new Military Posture in the Black Sea", https://newstrategycenter.ro/wp-content/uploads/ 2019/02/Policy-Paper-New-Strategy-Center-Centro-Studi-Internazionali2019.pdf (01 Haziran 2020 tarihinde erişildi).

Warsaw Summit Communiqué, https://www.nato.int/cps/en/natohq/official_ texts_133169.htm (28 Mayıs 2018 tarihinde erişildi).

Blue Black Sea: New Dimensions of History, Security, Politics, Strategy, Energy and Economy, (ed. G. Saynur Bozkurt), Cambridge Scholars Publishing, UK, 2013.

Black Sea Security Program-2013, (ed. Sergei Konoplyov, Lada Roslycky, Sergey Yeremko), Harvard Publ., USA, 2013.

\section{Kitap ve Makaleler}

BÖLÜKBAŞI, Deniz, Dışiş̧leri İskelesi, Dış̧işleri'nde 34 Yll, Doğan Kitap: İstanbul, 2011.

DUDAU, Radu, "The Black Sea: Romania's Energy Gateway", Black Sea Security Program-2013, Ed. Sergei Konoplyov-Lada Roslycky-Sergey Yeremko, Harvard Publ., USA 2013. ss. 78-81. 
FRIEDMAN, George, "Ukraine, Iraq and a Black Sea Strategy", https://worldview.stratfor.com/article/ukraine-iraq-and-black-sea-strategy (30 Mayıs 2020 tarihinde erişildi).

GABER, Yevgeniya, "Security Triangle in the Black Sea Region: Turkey, Russia, United States", Panaroma of Global Security Environment 2017-2018, Ed. Robert Ondrejcsak vd., Stratpol, Bratislava, 2018, ss. 198-220.

KONOPLYOV, Sergei-DELANOE, Igor, "Continuities and Ruptures: Tracking the US Interests in the Black Sea Area in the Context of the "Pivot Asi", Black Sea Security Program-2013, Ed. Sergei Konoplyov-Lada Roslycky-Sergey Yeremko, Harvard Publ., USA 2013. ss. 4-16.

LEFFLER, Melvyn P., "Strategy, Diplomacy, and the Cold War: The United States, Turkey, and NATO, 1945-1952", The Journal of American History, 71/4, (Mart 1985), ss. 807-825.

MEYER, Mihail, “18. Yüzyıldan Günümüze Rusya ve Türkiye İlişkileri”, Dünden Bugüne Türkiye ve Rusya, Der. Gülten Kazgan-Natalya Ulçenko, İstanbul Bilgi Üniversitesi, İstanbul 2003.

MITCHELL, Lincoln A., "More than Location: Crafting a US Policy for the Black Sea Region", Southeast European and Black Sea Studies, 8 (2), 2008, ss. 129140.

SANDERS, Deborah, Maritime Power in the Black Sea, Ashgate Publishing Limited, UK 2014.

URCOSTA, Ridvan, "U.S. Advance and Russia's Deep Concerns: The Operations Center in Ochakiv", https:/www.academia.edu/38869244/U.S._Advance _and_Russias_Deep_Concerns_The_Operations_Center_in_Ochakiv(23 Nisan 2020 tarihinde erişilidi). 
